\title{
Review
}

\section{Non-apoptotic cell death in animal development}

\author{
Lena M Kutscher ${ }^{1}$ and Shai Shaham ${ }^{* 1}$
}

Programmed cell death (PCD) is an important process in the development of multicellular organisms. Apoptosis, a form of PCD characterized morphologically by chromatin condensation, membrane blebbing, and cytoplasm compaction, and molecularly by the activation of caspase proteases, has been extensively investigated. Studies in Caenorhabditis elegans, Drosophila, mice, and the developing chick have revealed, however, that developmental PCD also occurs through other mechanisms, morphologically and molecularly distinct from apoptosis. Some non-apoptotic PCD pathways, including those regulating germ cell death in Drosophila, still appear to employ caspases. However, another prominent cell death program, linker cell-type death (LCD), is morphologically conserved, and independent of the key genes that drive apoptosis, functioning, at least in part, through the ubiquitin proteasome system. These non-apoptotic processes may serve as backup programs when caspases are inactivated or unavailable, or, more likely, as freestanding cell culling programs. Non-apoptotic PCD has been documented extensively in the developing nervous system, and during the formation of germline and somatic gonadal structures, suggesting that preservation of these mechanisms is likely under strong selective pressure. Here, we discuss our current understanding of non-apoptotic PCD in animal development, and explore possible roles for LCD and other non-apoptotic developmental pathways in vertebrates. We raise the possibility that during vertebrate development, apoptosis may not be the major PCD mechanism.

Cell Death and Differentiation (2017) 24, 1326-1336; doi:10.1038/cdd.2017.20; published online 17 February 2017

Facts

- Linker cell-type death (LCD) is the first cell death program found to proceed independently of caspases, and as a normal part of animal development.

- Germ cell death in Drosophila requires the serine protease HtrA2/Omi and involves mitochondria and lysosomes.

- Disruption of apoptotic genes in the mouse does not block most developmental cell death.

\section{Open Questions}

- Why is caspase-independent cell death often associated with germline and gonadal development?

- Is vertebrate LCD a freestanding developmental cell death program, or a backup to apoptosis?

- How prevalent is LCD in vertebrate development, and how conserved are the molecular players?

- How can non-apoptotic developmental cell death in vertebrates be tracked?

The term programmed cell death $(\mathrm{PCD})$ was first coined to describe cell elimination that occurs at precise locations and times during animal development. ${ }^{1}$ This process is key for sculpting tissues and organs, for removing excess or unnecessary cells, and for tissue homeostasis. The reproducible and consistent patterns of cell death in developing animals led to the idea that specific genes drive the phenomenon. Indeed, genes promoting apoptosis, a form of PCD characterized by chromatin condensation, membrane blebbing, and cytoplasm compaction ${ }^{2}$ (Figure 1a), were initially isolated in Caenorhabditis elegans. ${ }^{3}$ The discovery that the $C$. elegans caspase gene ced-3 is required for developmental apoptosis, and the subsequent realization that caspase homologs in Drosophila and in vertebrates also promote apoptosis, demonstrated that underlying the stereotypical morphological signature is a conserved molecular program. ${ }^{4,5}$ In species as diverged as $C$. elegans and the mouse, apoptosis is mediated by caspase proteases, activated by a conserved scaffolding protein called CED-4 in C. elegans and Apaf-1 in the mouse. Bcl-2 family proteins act upstream of CED-4/Apaf- 1 to control its activation. This occurs by direct binding in $C$. elegans, ${ }^{6}$ or through release of mitochondrial cytochrome $C$, which binds Apaf-1 in mammals. ${ }^{7}$ For a comprehensive review see Fuchs and Steller. ${ }^{8}$

Although initial reports of mice harboring knockout mutations in caspase genes, in Apaf-1, or in both Bax and Bak suggested that these genes play important roles in vertebrate developmental cell death, ${ }^{9-14}$ breeding mutants onto different genetic backgrounds revealed that homozygous knockout mice were not only born, but could survive to adulthood, often exhibiting only minor defects. ${ }^{14-17}$ For example, while initial reports suggested that Apaf-1 mutant mice exhibit inappropriate webbing between the pentadactyl-limb digits, later

${ }^{1}$ Laboratory of Developmental Genetics, The Rockefeller University, 1230 York Avenue, New York, NY 10065, USA

${ }^{*}$ Corresponding author: S Shaham, Laboratory of Developmental Genetics, The Rockefeller University, 1230 York Avenue, New York, NY 10065, USA. Tel: +1 212 327 7126; Fax: +1 212327 7129; E-mail: shaham @ rockefeller.edu

Received 22.12.16; revised 18.1.17; accepted 19.1.17; Edited by E Arama; published online 17.2.17 
analysis revealed only a delay in the process, with complete culling within 2 days. ${ }^{12,13}$ Mutations in Caspase-3 or Caspase9 do not affect this process. ${ }^{11,18}$ Furthermore, while persistence of small webs is observed in Bax; Bak double mutants, this surviving tissue is a small fraction of what survives in $B m p$ mutants, where cell death is entirely blocked. ${ }^{19,20}$ Similarly, early studies of Caspase-3 mutants revealed mice with apparent skull fractures and protruding brain tissue, suggesting a vast excess of neurons, consistent with the observation that in some brain regions up to $80 \%$ of cells that are originally produced undergo PCD. ${ }^{10,21}$ Subsequent examination, however, revealed no increase in neuronal cell number. ${ }^{22}$ Rather, defects in the sutures that bind skull bones together appear to be the cause of skull disruption, ${ }^{23}$ and oozing of brain tissue is likely a consequence of the release of intracranial pressure to which the brain is normally subjected.

Although the absence of massive cell survival in Caspase-3 or Caspase- 9 mutants can be explained by redundant activities of these enzymes, as the mouse harbors 13 caspase genes, ${ }^{8}$ only a single Apaf-1 gene exists in the murine genome. ${ }^{12}$ Furthermore, studies of Bax; Bak double mutants suggest that developmental apoptosis is nearly entirely abrogated, yet some animals still develop normally. ${ }^{14}$ Thus, an alternative explanation may be the existence of caspaseindependent non-apoptotic processes. Cells dying with nonapoptotic features during development have been extensively described, ${ }^{24}$ yet little is known about the underlying molecular effectors of these alternative death programs, or their in vivo relevance.

The past decade has seen somewhat of a renaissance in studying non-apoptotic cell death programs, and gene pathways controlling these processes in developing animals are emerging. While most developmental cell death in Drosophila and $C$. elegans proceeds via apoptosis, these organisms also provide highly amenable settings to discover non-apoptotic pathways. Here, we describe our current understanding of molecularly characterized non-apoptotic cell death programs that operate during development. These include germ cell death, nurse cell death and salivary gland cell death in Drosophila, and linker cell death in C. elegans. We investigate possible conservation in vertebrates, and discuss ultrastructural studies of developing vertebrate embryos that support an important role for non-apoptotic cell death. We suggest, specifically, that the linker cell-type death (LCD) caspaseindependent program acts as a primary cell death mechanism, or as a backup when caspase-dependent processes fail in vertebrates.

\section{Germ Cell Death in Drosophila}

Pre-meiotic male germ cells undergo stochastic PCD in the adult fly testes, and dying cells display some apoptotic features, including cytoplasmic compaction and chromatin condensation $^{25}$ (Figure 2a). Dying germ cells are also TUNEL (terminal deoxynucleotidyl nuclear transferase dUTP nick end-labeling)-positive, suggesting chromosomal DNA fragmentation. Surprisingly, these wild-type cells are not stained with an antibody against cleaved Caspase-3, which binds the executioner caspases Drice and Dcp-1. ${ }^{25}$ Furthermore, cells still die when these caspases are knocked down, suggesting that germ cell death is non-apoptotic. Correspondingly, unlike apoptotic cells, mitochondria of dying wild-type germ cells appear deformed and swollen. ${ }^{25}$

Although germ cell death does not employ executioner caspases, it does require an Apaf-1-independent function of the initiator caspase Dronc. ${ }^{25}$ Mutations in Apaf-1/arkincrease cell death, perhaps because more Dronc is available to induce non-apoptotic death. ${ }^{25,26}$ Mutations in dronc result in a $40-60 \%$ decrease in death. This defect is specific, as lesions in the initiator caspases strica and dredd have no effect. The mechanism of Dronc action is not fully understood. However, lysosomal biogenesis proteins and the lysosomal protease cathepsinD are required for efficient demise, and an increase in reactive oxygen species (ROS) and cytoplasm acidification occurs. ${ }^{25}$ ROS and Dronc may promote lysosome membrane permeabilization, allowing release of cathepsinD and DNasell into the cytosol ${ }^{25}$ (Figure 2b). The release of DNasell may explain TUNEL staining in the absence of cleaved Caspase-3.

Yacobi-Sharon et al. $^{25}$ discovered that the mitochondrial serine protease $\mathrm{HtrA}$ /Omi plays an important role in germ cell death. Drosophila carrying deletions of either one or both htrA2/omi copies are viable, but exhibit male sterility associated with a decrease in germ cell death. Remarkably, htrA2/omi lesions in humans are associated with Parkinson's disease, ${ }^{27}$ and mutations in the Parkinson's disease- and mitochondrial-associated gene pink1 also cause a decrease in Drosophila germ cell death. Overexpression of a cytosolic version of $\mathrm{HtrA2/Omi} \mathrm{promotes} \mathrm{caspase-independent} \mathrm{cell}$ death in mammalian cells, ${ }^{28}$ accompanied by morphological changes similar to Drosophila germ cell death, although nuclear changes are not evident. ${ }^{25,28}$ Roles for mitochondria in Drosophila germ cell death are also supported by the findings that the Bcl-2 family proteins Debcl and Buffy, and the mitochondrial nuclease EndoG, promote death. ${ }^{25}$

In rodents, male germ cells undergo stochastic cell death that may be caspase independent. ${ }^{29,30}$ Mutations in the pro-apoptotic gene Bax do not block these deaths, suggesting possible involvement of non-apoptotic programs. ${ }^{31,32}$ Furthermore, mutations in the testes-specific serine protease inhibitor spink2 result in increased germ cell death in male mice. ${ }^{30}$ These observations provide circumstantial evidence that conserved pathways may control stochastic male germ cell death across species.

\section{Nurse Cell Death in Drosophila}

In the Drosophila ovary, 15 nurse cells provide a developing oocyte with proteins, mRNA, and organelles ${ }^{33}$ (Figure 2c). After extruding their cytoplasmic contents into the oocyte, nurse-cell remnants die. Dying wild-type cells exhibit chromatin condensation, but also autophagosomes, ruptured lysosomes and large vacuoles. ${ }^{34,35}$ Dying cells stain with acidification markers, autophagic markers and TUNEL, ${ }^{34-37}$ raising the possibility that more than one cell death program is involved.

Whether caspases promote nurse cell death is debated. Some studies report no activated caspases in dying cells, ${ }^{38,39}$ whereas others report immunoreactivity using an activated Caspase-3 antibody. ${ }^{36,37}$ Mutants in Drosophila inducers of apoptosis do not exhibit nurse cell survival, suggesting a 

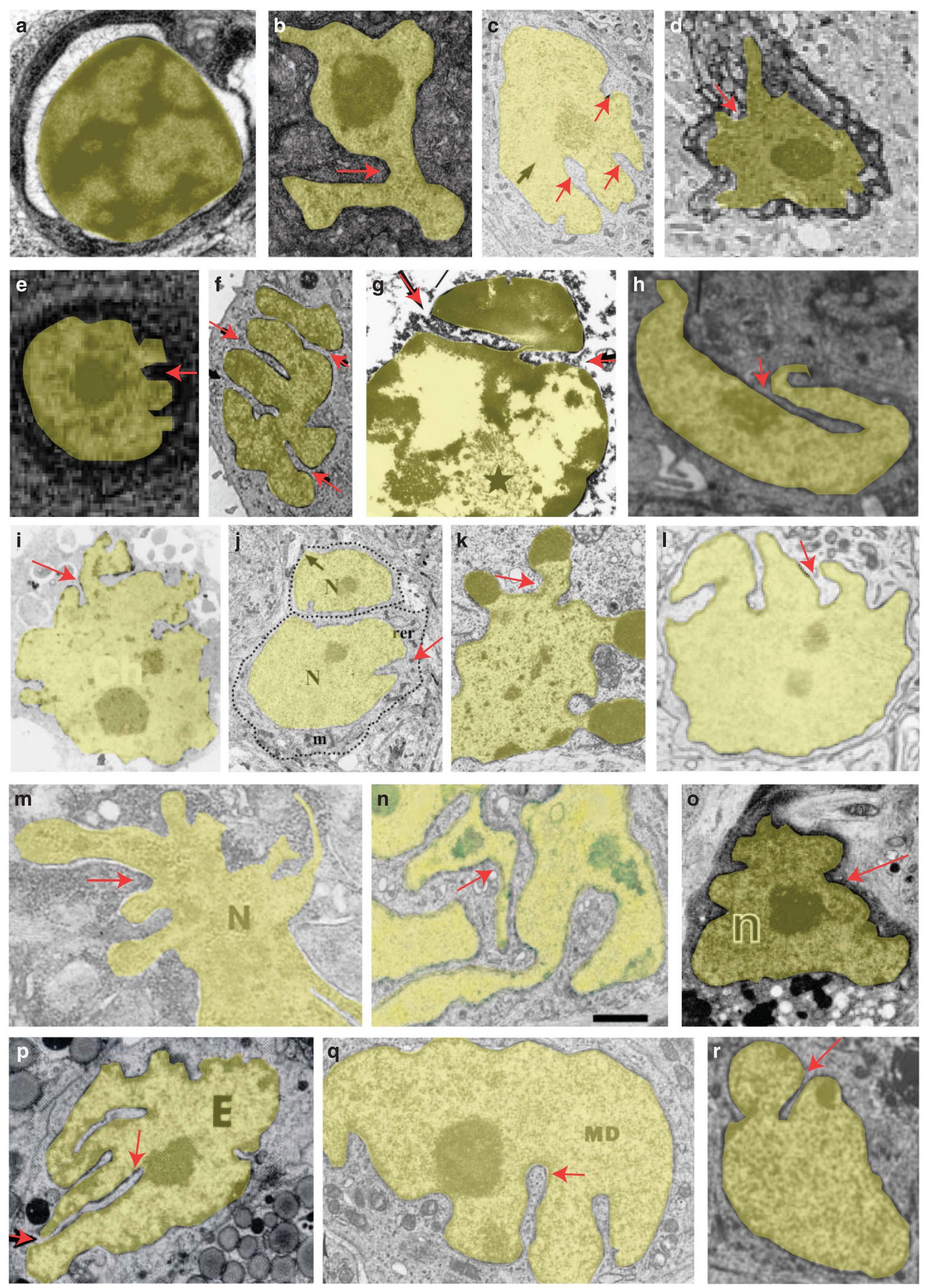
caspase-independent process, ${ }^{40,41}$ and some studies suggest that overexpression of the caspase inhibitors diap1 or p35 also does not perturb death. ${ }^{37,38}$ However, other studies suggest that such overexpression weakly blocks death. ${ }^{42}$

Genetic studies demonstrate that nurse cell death still proceeds in dronc, dredd, strica, $d c p-1$ or drice caspase single mutants. ${ }^{42-44}$ However, dredd;strica or dcp-1;drice double mutants exhibit weak survival, suggesting that caspases may be relevant, but functionally redundant. ${ }^{42}$ Congruently, mutants in Apaf-1/ark, which functions upstream of initiator caspases, also exhibit weak nurse cell death defects. ${ }^{41}$

In developing nurse cells in vitro, the Caspase-3-inhibitor Z-DEVD-FMK blocks DNA fragmentation but not chromatin condensation. ${ }^{45}$ While mutations in inhibitor of caspaseactivated DNase (ICAD) cause a decrease in cleaved DNA, nurse cells still clear their DNA efficiently. ${ }^{46}$ In another study, however, mutants in dICAD displayed weak nuclear persistence, similar to Apaf-1/ark mutants. ${ }^{41}$ Together, these data suggest that caspases may play some role in nurse cell death.

The role of autophagy in nurse cell death is also unclear. Despite the presence of autophagosomes, autophagy-related protein levels are not increased in dying cells. ${ }^{35,38}$ However, one study reported that nurse cell nuclei persist in mutants of the autophagy genes atg 1 and atg $13 .^{36}$ This defect, however, is not fully penetrant, suggesting other processes are probably involved. ${ }^{36}$ atg7; dcp-1 double mutants exhibit similar defects to atg 7 single mutants, ${ }^{47}$ indicating that these other pathways may be caspase independent.

Lysosomes may play important roles in nurse cell death and removal (Figure 2d). Mutants in DNasell and the lysosomal trafficking protein deep orange/Vps 18 exhibit persisting nurse cell nuclei, ${ }^{35,47}$ as do mutants in the lysosomal fusion protein Spinster and the protease CathepsinD. ${ }^{35}$ While Deep Orange is required in the engulfing follicle cells, DNasell and Spinster appear to function cell autonomously. ${ }^{35}$ Thus, lysosomes may have multiple activities in nurse cell death, although these results are complicated by the fact that some of these mutants perturb cytoplasm transfer, which may delay or impede death. ${ }^{34}$

Recent research raises the possibility that the primary nurse cell death mechanism may be phagoptosis, such that nurse cell death is non-autonomously promoted by surrounding follicle cells. ${ }^{48}$ Consistently, mutants in the engulfment genes draper and ced-12 display nurse cell survival, and Draper is required for nurse cell acidification. ${ }^{48}$ Furthermore, ablation of surrounding follicle cells strongly inhibits death, although cytoplasm transfer is also blocked. ${ }^{48}$ Thus, it is possible that nurse cell death may be an assisted suicide.

\section{Salivary Gland Cell Death in Drosophila}

Drosophila salivary glands are larva-specific structures that are rapidly degraded after puparium formation ${ }^{49,50}$ (Figure 2e). Dying wild-type cells exhibit apoptotic features, but also an abundance of autophagosomes and nuclear separation from the cytoplasm. ${ }^{51,52}$ Both autophagy and caspase genes are induced during salivary gland cell death, ${ }^{53,54}$ although the precise contribution of each is not fully understood. Caspases may be dispensable for death. Loss-of-function mutants in dronc or drice caspase genes or in Apaf-1/ark do not strongly perturb salivary gland death and degradation. ${ }^{50,55}$ While expression of the caspase inhibitor p35 halts DNA fragmentation and nuclear lamin cleavage, ${ }^{51,52}$ it does not result in intact cells. ${ }^{54}$ Instead, fragments appear to persist inappropriately, ${ }^{50}$ suggesting a cell degradation role for caspases.

Autophagy is induced prior to salivary gland cell death, and in the absence of the autophagy-related gene atg18, salivary glands are not properly degraded, exhibiting vacuolated cell fragments $^{50}$ (Figure 2f). These findings provide in vivo evidence for a role of autophagy in degrading dying cells. ${ }^{50}$ Combining autophagy and caspase inhibition blocks gland

Figure 1 Crenellated nuclei (pseudocolored yellow, red arrows) are prevalent in disease models and in normal development. (a) In apoptosis, chromatin is highly condensed and darkly staining, but the nuclear envelope remains round ( $C$. elegans cell). (b) In linker cell death, the nuclear envelope is crenellated, with indentations apparent even using Nomarski optics. Reprinted from Blum et al. ${ }^{63}$ (c) In a mouse model of Huntington's disease, crenellated nuclei are prominent in almost all the cells of the striatum. Black arrow, neuronal nuclear inclusion. Reprinted from Davies et al. ${ }^{70}$ with permission from Elsevier. (d) They are also prevalent in dark neurons of a mouse model of Huntington's disease. ${ }^{71}$ Copyright 2000 National Academy of Sciences. (e) In brain autopsy samples of a Huntington's disease patient, crenellated nuclei with uncondensed chromatin are present. Reprinted from Maat-Schieman et al..$^{77}$ with permission from Oxford University Press. (f) In a cell line overexpressing a pathogenic Ataxin-3, crenellated nuclei were apparent prior to non-apoptotic cell death. Reprinted from Evert et al..$^{74}$ with permission from Oxford University Press. (g) In the CAG repeat disease dentatorubral-pallidoluysian atrophy, autopsy samples from patients have nuclear membrane indentations in some granule cells in the cerebellar cortex. Star, intranuclear inclusion. Reprinted from Takahashi et al. ${ }^{75}$ with permission from Elsevier. (h) Dying cells from the developing palatal shelf display crenellated nuclei. Reprinted from Schweichel and Merker ${ }^{83}$ with permission from John Wiley and Sons (Publisher). (i) While Caspase-9 null embryonic stem cells rarely die after UV treatment, those that do display LCD features, including open chromatin, swollen organelles, and crenellated nuclear envelope. Ch, chromatin. Reprinted from Hakem et al. ${ }^{9}$ with permission from Elsevier. (j) Degenerating motoneurons in Bak knockout mice have crenellated nuclei, and are small and atrophied. N, nucleus. $\mathrm{m}$, mitochondria. rer, rough endoplasmic reticulum. Black arrow, synapse. Dotted line, soma. Republished with permission from Society for Neuroscience, from Sun et al.: ${ }^{88}$ permission conveyed through Copyright Clearance Center, Inc. (k) Degenerating motoneurons in a wild-type stage 24 chick spinal cord have indented nuclei. ${ }^{91}$ Adapted from (01974 O'Connor and Wyttenbach. Journal of Cell Biology 60: 448-459. DOI: 10.1083/jcb.60.2.448. (I) Non-apoptotic dying retinal ganglion cells in the same organism have crenellated nuclei after axotomy. Reprinted from Borsello et al. ${ }^{93}$ with permission from John Wiley and Sons (Publisher). (m) Peripherally deprived ciliary ganglion neurons in the embryonic chick display highly indented nuclei. ${ }^{94} \mathrm{~N}$, nucleus. Adapted from @1976 Pilar and Landmesser. Journal of Cell Biology 68: 339-356. DOI: 10.1083/jcb.68.2.339. (n) Avian motoneurons in culture adopt either an apoptotic morphology or an LCD morphology as shown here, with highly crenellated nuclei, and swollen organelles at later timepoints (not shown). Scale bar $=1 \mu \mathrm{m}$. Reprinted from Brunet et al. ${ }^{95}$ with permission from John Wiley and Sons (Publisher). (o) In the presence of caspase inhibitors, motoneurons in the chick acquire non-apoptotic morphology. $n$, nucleus. Reprinted from Yaginuma et al. ${ }^{96}$ with permission from Elsevier. (p) Mouse uterine epithelial cells die shortly after implantation, and these cells display irregularly shaped nuclei. Reprinted from Parr et al. ${ }^{101}$ with permission from Oxford University Press. (q) Regressing Müllerian duct cells in wild-type mice have open chromatin, crenellated nuclei, and swollen organelles. Reprinted from Dyche ${ }^{108}$ with permission from John Wiley and Sons (Publisher). MD, Müllerian duct epithelial cell. (r) Explant cultures of degenerating Müllerian duct cells from rats share the same features. Reprinted from Price et al. ${ }^{111}$ with permission from John Wiley and Sons (Publisher) 
a

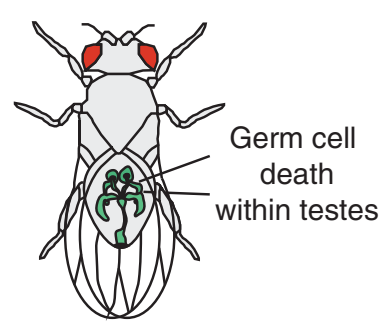

C

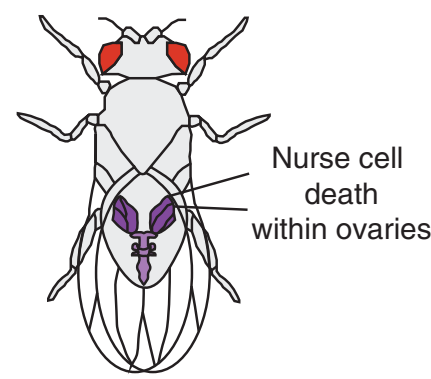

e

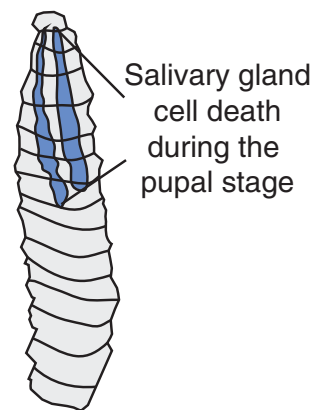

b

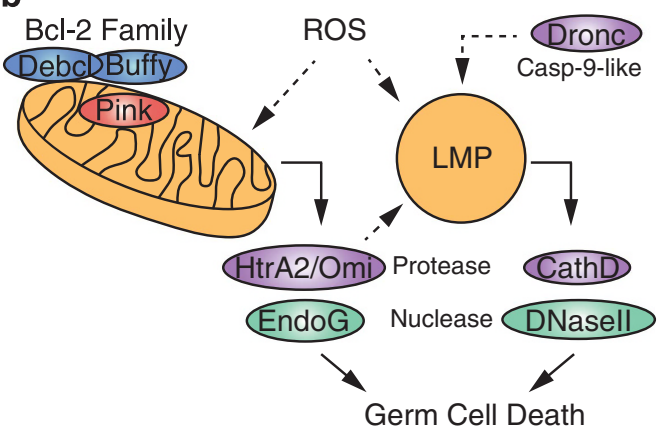

d

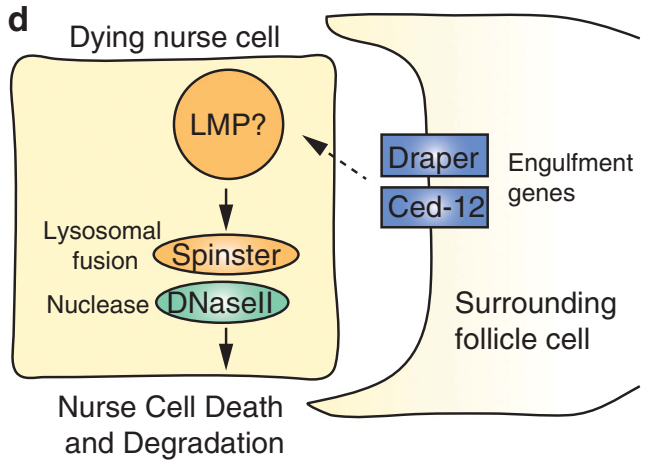

f

Engulfment gene

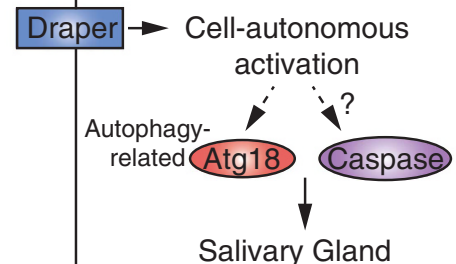

Cell Death and Degradation

Figure 2 Non-apoptotic cell death in Drosophila. (a) In adult males, germ cell death occurs within the testes (green). (b) Dronc, a Caspase-9-like protease, functions in an apoptosome-independent fashion to perhaps trigger lysosome membrane permeabilization (LMP), allowing the release of the protease CathepsinD and the nuclease DNasell. At the mitochondria, Bcl-2 family members Debcl and Buffy function on the outer membrane, and the Parkinson-related protein Pink1 functions within. ROS may trigger release of the serine protease HtrA2/Omi and the nuclease EndoG. ${ }^{25}$ (c) In the female adult fly, nurse cell death occurs within the ovaries (purple). (d) The surrounding follicle cells may induce nurse cell death, using the engulfment receptors Draper and Ced-12 via phagoptosis. Downstream events may lead to lysosome membrane permeabilization (LMP) and the release of the lysosomal fusion protein Spinster and the nuclease DNasell. Caspases and autophagy may be minimally involved. (e) After puparium formation, large larval salivary glands (blue) die and degrade before the adult fly hatches. (f) The engulfment gene Draper is required cell-autonomously within the salivary glands to drive cell death, and may lead to downstream activation of autophagy genes like Atg18. Caspases may work in parallel

degradation further, but not cell death, suggesting these pathways function in parallel. ${ }^{50}$ Cell death can be inhibited by overexpression of the PI3K active subunit Dp110 and p35, suggesting involvement of a PI3K target. ${ }^{50}$

The salivary glands are large structures, and their phagocytosis by neighboring cells is not well understood. The engulfment gene draper is required to induce autophagy cellautonomously in the salivary gland cells, and not for engulfment, ${ }^{52,56}$ suggesting an unexpected and intimate connection between engulfment and degradation genes. Such a connection had been described for nurse cell death (see above ${ }^{48}$ ). In $C$. elegans, engulfment genes also appear important in some contexts for promoting nuclease activation for cell degradation. ${ }^{57}$

\section{Linker Cell Death in C. elegans}

The $C$. elegans male-specific linker cell leads gonad elongation. During the L4 larva-to-adult transition, the cell dies, allowing gonad-cloaca fusion for sperm release and male fertility (Figure 3a). The dying linker cell is engulfed by its neighboring U.I/rp cells. ${ }^{58}$ Morphologically, wild-type linker cell death is non-apoptotic: chromatin is not condensed, the nuclear envelope becomes crenellated, and mitochondria and 
a
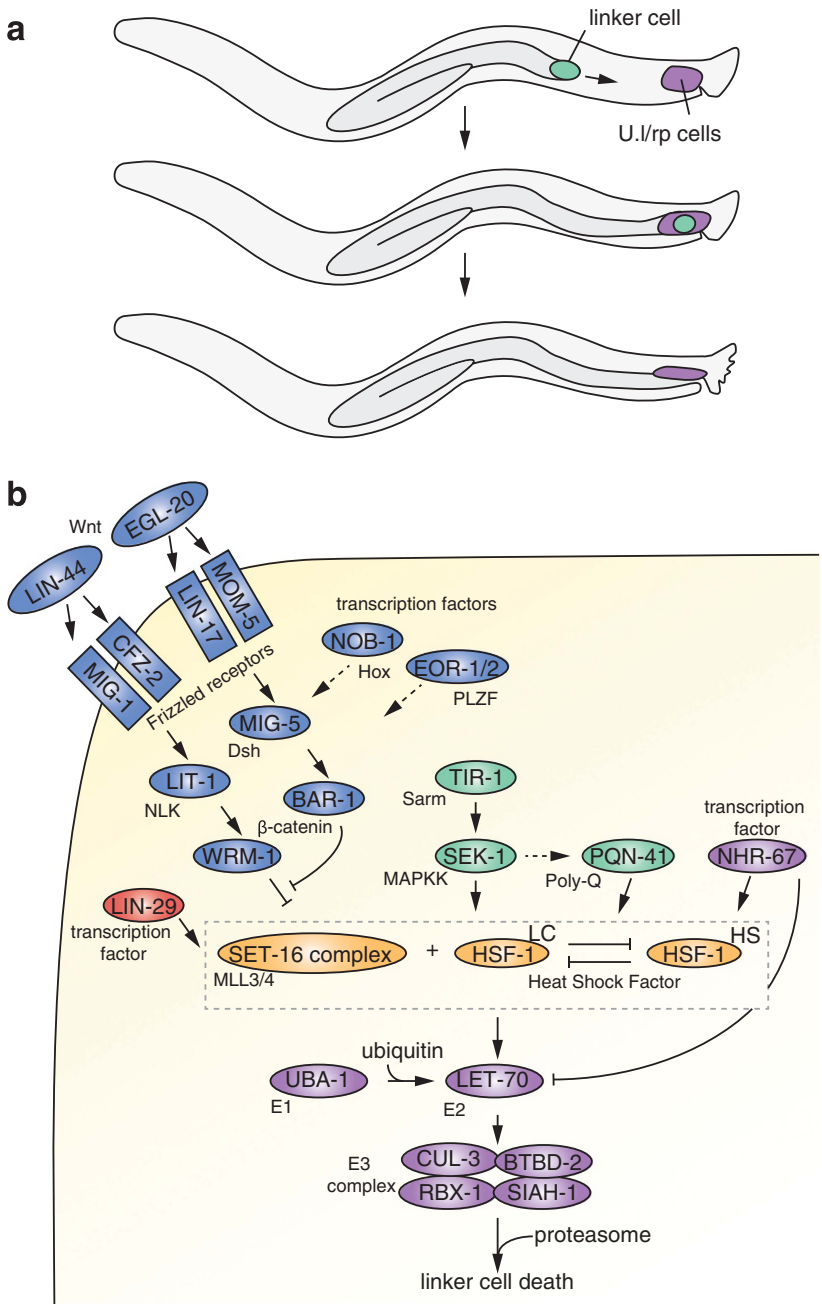

Figure 3 The linker cell dies independent of caspases. (a) The linker cell (green) is a male-specific cell that leads the elongation of the developing gonad. Once it reaches its destination, it dies, and is engulfed by the U.I/rp cells (purple), allowing fusion of the gonad with the cloaca. (b) Multiple regulatory pathways are required to ensure the linker cell dies at the proper place and time. These pathways include two antagonistic Wnt pathways (blue), the developmental timing protein LIN-29 (red), Sarm/TIR-1, the MAPKK SEK-1, and the polyglutamine protein PQN-41 (green), and the nuclear hormone receptor NHR-67 (purple). These pathways converge on the heat-shock factor HSF-1, which acts in parallel with the SET-16 histone methyltransferase complex (orange). The pro-death function of HSF-1 competes with its pro-survival function. HSF-1 may transcriptionally upregulate the E2 ubiquitinconjugating enzyme LET-70 (purple). The transfer of ubiquitin from the E1 UBA-1, through LET-70, to an E3 complex may confer substrate specificity, leading perhaps to degradation of key proteins by the proteasome, resulting in linker cell death

endoplasmic reticulum swell ${ }^{58}$ (Figure 1 b). Death proceeds even when all four caspase genes are inactivated, and mutations in other core apoptotic genes also fail to prevent death ${ }^{58,59}$ Thus, linker cell death represents the first example of a non-apoptotic caspase-independent cell death process required for development. The morphology of dying linker cells is frequently seen in vertebrate development, and we have termed this appearance LCD. Importantly, although invaginated membranes are often artifacts of EM fixation, this is not the case for linker cell nuclear crenellation, as this feature is detected in the living animal under light microscopy. In vertebrate settings, LCD ultrastructural features are distinguished from EM artifacts or natural variability as they are seen only at specific developmental times, and accompany only populations of dying cells and not their neighbors (see below).

Work in our lab revealed multiple control pathways promoting linker cell death. This death must be tightly regulated, as premature demise blocks gonad elongation, resulting in sterility. ${ }^{60}$ Two opposing Wnt pathways control death onset (Figure 3b). One pathway, consisting of the Wnt ligand LIN-44, secreted by some tail cells, the Frizzled receptors MIG-1 and CFZ-2, the Nemo-like kinase LIT-1 and the $\beta$-catenin WRM-1, all acting in the linker cell, appears to block linker cell death, and may prevent premature death. ${ }^{61}$ The LIN-44/Wnt pathway is inhibited by a second Wnt pathway, consisting of EGL-20/ Wnt, secreted by the engulfing cells, and LIN-17/Frizzled and MOM-5/Frizzled, acting within the linker cell with MIG-5/ Disheveled and BAR-1/ $\beta$-catenin, which promotes death. ${ }^{61}$ Two transcription factors, NOB-1/Hox and the EOR-1/-2/PLZF complex, likely control the EGL-20/Wnt pathway. ${ }^{62}$

In parallel, TIR-1, the $C$. elegans ortholog of mammalian Sarm, activates the MAPKK protein SEK-1 to promote death. ${ }^{63}$ SEK-1 may promote expression of the polyglutamine-repeat protein PQN-41. PQN-41 expression is induced in the linker cell at the onset of death, and a GFP-tagged version forms puncta within the linker cell. ${ }^{63}$

The zinc-finger protein LIN-29, a component of a developmental timing program, ${ }^{64}$ also promotes death, as does the nuclear hormone receptor NHR-67. ${ }^{62}$ These genes appear to act independently of and in parallel to the Wnt and MAPKK pathways. ${ }^{62}$

Linker cell death can be restored in mutants carrying lesions in the upstream control pathways by a gain-of-function mutation in HSF-1, a highly conserved transcriptional regulator of the heat shock and other stress responses. HSF-1 loss-of-function blocks death. Thus, HSF-1 likely functions downstream of or in parallel to the regulators described above. ${ }^{61} \mathrm{~A}$ pro-death role for HSF-1 is surprising, as HSF-1 is typically responsible for promoting survival in response to stress. In animals exposed to a heat-shock $4 \mathrm{~h}$ before death onset, the linker cell survives inappropriately, suggesting that the pro-death and pro-survival functions of HSF-1 may compete. ${ }^{61}$ Genetically, HSF-1 functions at the same step as the SET-16/MLL3/4 H3K4 histone methyltransferase complex. ${ }^{62}$

Genetic, expression and functional studies suggest that HSF-1 may work by transcriptionally activating components of the ubiquitin proteasome system. ${ }^{61}$ The single $C$. elegans $\mathrm{E} 1$ enzyme, UBA-1, is required through activity of the E2 ubiquitin-conjugating enzyme LET-70, homologous to mammalian UBE2D2. LET-70/UBE2D2 appears to act through an E3 ubiquitin ligase complex comprising the cullin CUL-3, the ring box protein RBX-1, the BTB domain-containing protein BTBD-2 and perhaps SIAH-1. Substrates of this E3 complex are unknown, but may provide critical clues to how this caspase-independent cell death is executed. It is possible, for example, that degradation of a critical substrate is the key to the lethal effects of the pathway. Correspondingly, proteasome $19 \mathrm{~S}$ regulatory domain components are required for linker cell death. ${ }^{61}$ 
Molecular components related to those promoting linker cell death have been implicated in degeneration and death in other settings. Wallerian degeneration is a process by which the distal process of an injured axon degenerates, leaving the cell body intact. Wallerian degeneration slow $\left(\mathrm{Wld}^{\mathrm{S}}\right)$ mice have persistent axotomized axons ${ }^{65}$ caused by an abnormal protein fusion between an NAD ${ }^{+}$synthesis protein, NMNAT, and the ubiquitin factor E4B (Ube4b). ${ }^{66}$ Recent work has revealed that mutations in $d S a r m$, the Drosophila homolog of C. elegans tir-1 required for linker cell death, also suppress Wallerian degeneration in the fly. ${ }^{67}$ Likewise, murine Sarm promotes Wallerian degeneration in vivo. ${ }^{67}$ Overexpression of the SAMTIR domains of murine Sarm in cell culture promotes death that appears non-apoptotic, as it proceeds in the presence of caspase inhibitors. ${ }^{68}$

In the linker cell, TIR-1/Sarm1 regulates expression of the polyQ-repeat protein, $P Q N-41 .^{63}$ While $P Q N-41$ function is not well understood, its sequence raises the hypothesis that polyQ-expansion neurodegenerative diseases, such as
Huntington's disease, may be instances of a developmental cell death program gone awry. ${ }^{69}$ Supporting this, in a mouse Huntington's disease model, dying cells exhibit swollen mitochondria and Golgi, and crenellated nuclei, strikingly reminiscent of linker cell death ${ }^{70}$ (Figures 1c and d). TUNEL staining is not detected in dying neurons. ${ }^{71}$ Crenellated nuclei are also found in dying cells of other polyQ disease models and in human patients ${ }^{72-77}$ (Figures 1e-g).

Intersegmental muscles (ISMs) of the moth, Manduca sexta, may also prove fertile ground for exploring similarities with linker cell death. Wild-type ISM cells that die during metamorphosis exhibit non-apoptotic features: chromatin condensation is not seen, nor are DNA fragmentation, or membrane blebbing. ${ }^{78}$ However, ubiquitin expression is induced, similar to linker cell death. ${ }^{79}$ Furthermore, an E1 ubiquitin-activating enzyme, several E2 ubiquitin-conjugating enzymes and E3 ubiquitin ligases are induced. ${ }^{80}$ Molecular characterization of these proteins and their targets may reveal similarities to linker cell death.

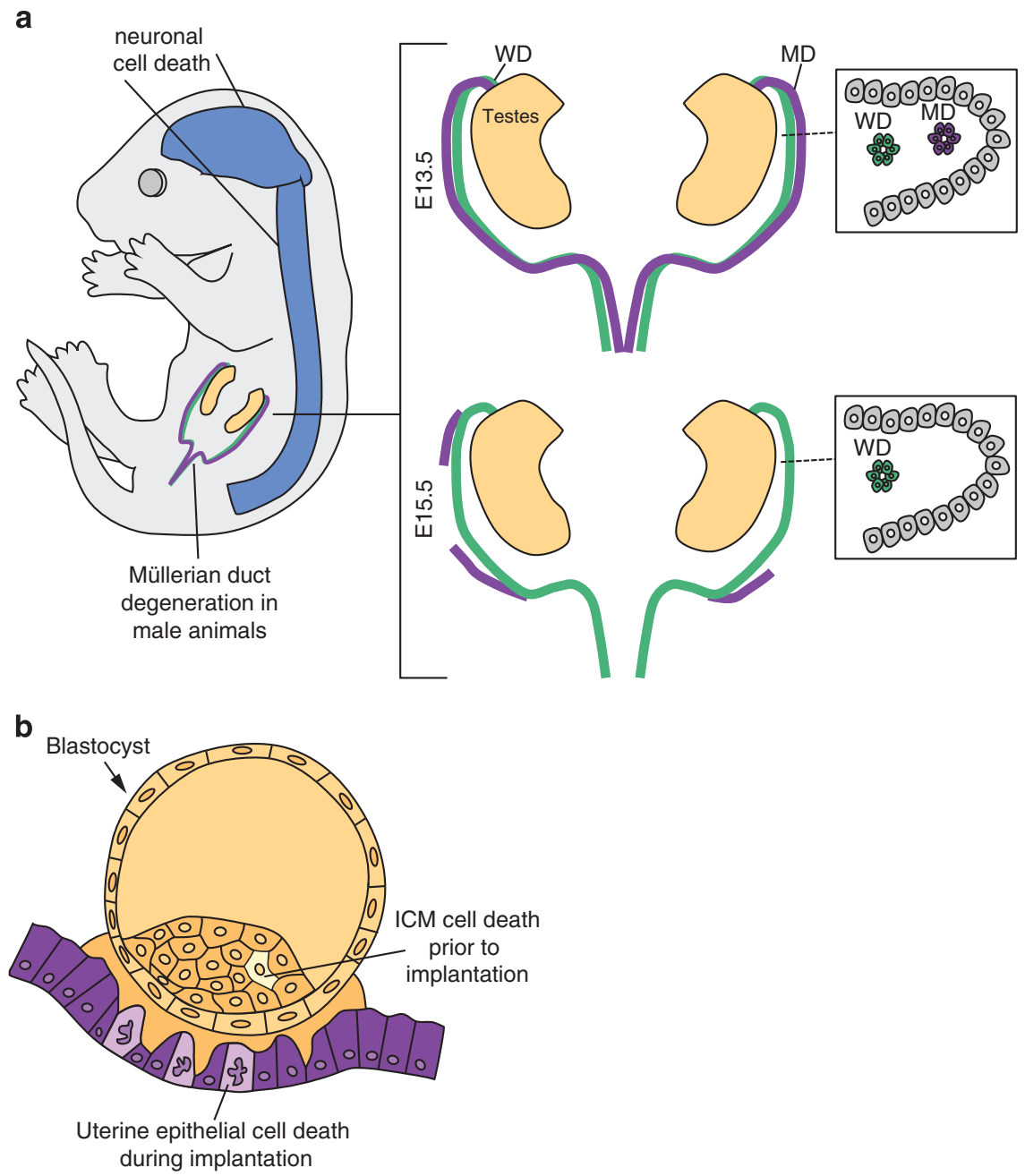

Figure 4 Non-apoptotic cell death occurs in vertebrate development. (a) In the developing mouse embryo, neurons within the brain and spinal cord (blue) die. In male mice at E13.5, the Müllerian duct (MD, purple) and the Wolffian duct (WD, green) are both present in the immature reproductive system. Signal from the testes cause the Müllerian duct to degenerate by E15.5. (b) Cell death occurs in the inner cell mass of the blastocyst (yellow) prior to implantation. Uterine epithelial cells (purple) die upon implantation of the blastocyst and may be entosed by the trophoblast cells 


\section{Non-apoptotic Cell Death in Vertebrate Development}

Although non-apoptotic cell death pathways like necroptosis have been described in vertebrate cells, none appear to be required for normal development, as elimination of key genes regulating these processes does not affect development or developmental cell death. ${ }^{81,82}$ Nonetheless, evidence that non-apoptotic cell death has important roles in vertebrate development abounds, including but not limited to the formation of the mammalian palate ${ }^{83}$ (Figure 1h), cornification of epidermal keratinocytes, ${ }^{84}$ and lysosome-mediated mammary gland involution post-lactation. ${ }^{85}$ In the following subsections, we highlight four salient examples that raise the possibility that non-apoptotic cell death programs may indeed be the norm during vertebrate development. Whether such programs back up, act in parallel, or function independently of apoptosis is not easy to distinguish, as a key test for their nonapoptotic nature is whether they proceed without apoptotic genes- inherently unnatural settings. We have therefore focused on processes that are genetically non-apoptotic, and which also have obvious non-apoptotic features in the developing wild-type animal.

Cell death in the vertebrate nervous system. Initial studies of mice harboring lesions in core apoptotic components, including Apaf-1, the initiator Caspase-9, and the executioner Caspase-3, suggested important roles for these genes in nervous system development. Apaf-1 ${ }^{-1-}$, Caspase- $3^{-1-}$, and Caspase $-9^{-1-}$ animals exhibited exencephaly associated with neural tube defects, and most animals died perinatally, ${ }^{9-13}$ and presented with mitotically active immature neurons. ${ }^{86}$ Later studies revealed that genetic background was a strong contributor to these defects, and that mice carrying the same lesions in other genetic contexts could develop normally to adulthood. For example, Caspase- $3^{-/-}$ mice in a C57BL/6J genetic background survive to adulthood, but the same mutation in $129 \times 1 / S v J$ mice induces perinatal lethality. ${ }^{15}$ How then does cell death still occur? A number of studies suggest that alternative cell death pathways are likely to be at least as important as apoptosis in these mutants.

While embryonic stem cells lacking Caspase-9 exhibit resistance to pro-apoptotic agents, ${ }^{9}$ some mutant cells die and exhibit non-apoptotic LCD-like morphology, including a crenellated nuclear envelope, uncondensed chromatin, and swollen organelles (Figure 1i), suggesting that a process akin to linker cell death may be functioning. Supporting this, death of post-mitotic spinal cord and brain stem motoneurons (Figure 4a) appears to proceed normally in Caspase- $3^{-/-}$ and Caspase $-9^{-1-}$ animals even though TUNEL staining decreases, $^{86}$ suggesting that caspase-activated DNase (CAD), one of the enzymes responsible for cleaving chromosomal DNA during apoptosis, ${ }^{87}$ is not induced. Thus, cells appear to be dying in the absence of caspase activation. Indeed, dying cells lacking Caspase-3 or Caspase- 9 have different morphologies than wild-type cells, with reduced chromatin condensation. ${ }^{86}$ Similar studies in $\mathrm{Bax}^{-1-}$ animals reveal an increase in cell number, but the extra cells are small and atrophied, are not synaptically connected, and exhibit crenellated nuclei ${ }^{88}$ (Figure 1j). In Apaf-1 $1^{-1-}$ mutants, spinal and cranial motoneurons, and dorsal root ganglion sensory cell death numbers are normal compared with wild type, again suggesting that caspase-independent cell death mechanisms are important in the developing nervous system. ${ }^{89}$

Similar to mice, motoneurons are normally produced in excess during chick spinal cord development, and many subsequently die. ${ }^{90}$ Ultrastructurally, these dying wild-type cells possess either apoptotic or non-apoptotic morphologies, the latter exhibiting dilated organelles, open chromatin and an irregular nucleus ${ }^{91,92}$ (Figure 1k). Axotomized retinal ganglion cells or peripherally deprived ciliary ganglion cells have the same indented nuclear structure ${ }^{93,94}$ (Figures 11 and $\mathrm{m}$ ). Interestingly, wild-type chick motoneurons in culture can adopt similar morphologies (Figure 1n), and while these dying cells can be engulfed, they lack cleaved Caspase-3 staining or TUNEL staining. ${ }^{95}$ In vivo, these motoneurons still die in the presence of the Caspase-3 inhibitor Ac-DEVD-CHO or the stronger pan-caspase inhibitor Boc-D-FMK. ${ }^{96}$ Intriguingly, dying cells treated with caspase inhibitors have a crenellated nucleus, open chromatin, and swollen organelles, ${ }^{96}$ all features of LCD (Figure 10).

Cell death in the inner cell mass. Cell death is an early occurrence in vertebrate development, and is evident in the inner cell mass (ICM) prior to implantation ${ }^{97}$ (Figure $4 \mathrm{~b}$ ). These cell deaths in a wild-type mouse blastocyst are characterized by condensed chromatin and loss of nuclear membrane integrity, but also swelling of the endoplasmic reticulum. ${ }^{98}$ Single mutants of apoptotic factors do not seem to block blastocyst development, suggesting that cell death likely proceeds normally. ${ }^{97}$ Supporting this notion, when hamster or mouse embryos are cultured from the 8-cell stage to the blastocyst stage in vitro in the presence of the Caspase-3 inhibitor Ac-DEVD-CHO, no noticeable effects on development are observed. ${ }^{99}$ Dying cells in the ICM of wildtype bovine blastocysts exhibit a mix of apoptotic and nonapoptotic features. ${ }^{100}$ Some dying cells have condensed chromatin but weak TUNEL staining, while others have moderate TUNEL staining. ${ }^{100}$ Furthermore, only low transcript levels of key apoptotic factors, including Caspase-3 and Caspase-9, are detected. ${ }^{100}$ Thus, caspases, and perhaps other apoptotic proteins, may not be required for ICM cell death.

Death of uterine epithelial cells during implantation. At the site of implantation, uterine epithelial cells die and are internalized by embryonic trophoblast cells ${ }^{101}$ (Figure 4b). These dying epithelial cells in normal development exhibit compacted chromatin, but also swollen organelles and irregular nuclear envelopes ${ }^{101,102}$ (Figure 1p). One study reported activated Caspase-3 in TUNEL-positive dying cells in wild-type hamster and mouse uterine epithelial cells at the site of implantation. ${ }^{99}$ Additionally, inhibiting Caspase-3 with Ac-DEVD-CHO in the uterus stopped implantation in both species, suggesting that Caspase-3 may be necessary for cell death..$^{99}$ However, Caspase $-3^{-1-}$ or Apaf- $1^{-1-}$ adult female mice are fully fertile. ${ }^{15,16}$ Furthermore, a subsequent detailed examination of the process revealed that neither cleaved Caspase-3 nor TUNEL are detected in dying wildtype epithelial cells immediately adjacent to trophoblast cells. ${ }^{103}$ Entosis, engulfment of a living cell followed by 
degradation, has been suggested as a mechanism, as the kinase ROCK, which controls entosis in cell culture, ${ }^{104}$ appears to be required. ${ }^{103}$ The ultrastructure of these dying cells was not reported, and could be used to distinguish among different alternative cell death mechanisms.

Cell death in the Müllerian duct. In developing mammals, sex specification occurs early in embryogenesis. Initially, both sexes form a Wolffian duct (WD), which develops into male urogenital structures, and a Müllerian duct (MD), which gives rise to female reproductive structures. In females, the WD degenerates, whereas the MD regresses in males ${ }^{105}$ (Figure $4 a$ ). MD regression is initiated by the secreted TGF- $\beta$ protein $\mathrm{AMH}$ (anti-Müllerian hormone). ${ }^{106}$ In the absence of $\mathrm{AMH}$, the MD persists, and results in female organs alongside the male urogenital system. This leads to infertility, as the ectopic organs physically block sperm release. ${ }^{107}$

The morphology of dying wild-type MD epithelial cells in rats, mice and rabbits, is non-apoptotic: chromatin in degenerating cells is uncondensed, and the nuclear envelope is crenellated $^{108-110}$ (Figure 1q). These features are reminiscent of linker cell death, suggesting that MD degeneration proceeds similarly. Degenerating female rabbit WD cells also have crenellated nuclei. ${ }^{110} \mathrm{MD}$ and WD degeneration can be reproduced in an organ culture system, and dying cells here exhibit open chromatin and nuclear crenellation ${ }^{111}$ (Figure 1r).

Regressing wild-type MD cells are TUNEL positive, ${ }^{112}$ and cleaved Caspase- 3 is detected in some dying cells. ${ }^{107} \mathrm{How}$ ever, neither Caspase-3 nor other apoptosis mutants are reported to harbor defects in urogenital tract development. There are conflicting reports regarding the sterility of Apaf-1 $1^{-/-}$ mutants males; however, not all males are infertile. ${ }^{16,17}$ Caspase $-3^{-/}$male mice in the C57BL/6J genetic background are fully fertile. ${ }^{15}$ Thus, it is possible that LCD is the main cell death mechanism during MD and WD degeneration, with Apaf-1 and Caspase-3 either playing minor roles, or specifically promoting corpse degradation (see, e.g., ref. 96).

While the genes directly driving MD cell death are unknown, some of the upstream signaling events have been explored. Wnt7a signaling from MD epithelial cells allows surrounding mesenchymal cells to respond to $\mathrm{AMH},{ }^{113}$ likely by regulating expression and/or activation of receptors in the mesenchyme. ${ }^{114-116}$ Receptor engagement leads to activation of SMAD proteins, which then induce expression of Wnt4, and possibly other Wnts. ${ }^{116}$ Possible autocrine signaling leads to the activation of $\beta$-catenin, which promotes regression in the epithelial cells. ${ }^{112} \beta$-Catenin accumulates in the mesenchymal cytoplasm, and is present near the plasma membrane of MD epithelial cells. ${ }^{112}$ Mesenchyme-specific knockdown of $\beta$-catenin prevents MD degeneration. ${ }^{107}$ While both MD regression and linker cell death use $\beta$-catenin signaling to initiate cell death, $\beta$-catenin appears to function cell nonautonomously in the MD.

The matrix metalloproteinase MMP2 may be involved in signaling to initiate regression. ${ }^{117} \mathrm{Mmp2}$ is expressed at higher levels in the male mesenchyme, and this increase is abolished in the absence of $\mathrm{AMH} .{ }^{117}$ In organ culture, blocking MMP2 prevents MD degeneration, while activating MMP2 causes degeneration. ${ }^{117}$ However, MMP2 mutant mice are fertile, suggesting other genes are involved. ${ }^{118}$ Roles for
MMPs in linker cell death have not been described, but the adjacent gonad is known to secrete these proteins. ${ }^{119}$

Together, the examples described make a compelling case for the prevalence of caspase-independent non-apoptotic cell death during vertebrate development, with LCD playing, perhaps, an important role.

\section{Looking forward}

The studies reviewed here demonstrate that developmental cell death is a far more complex and poorly understood process than has been generally acknowledged, and that the often-interchangeable usage of the terms apoptosis and programmed cell death is highly misleading. Using single assays, such as TUNEL or activated caspase staining, appears insufficient to assign a mode of cell death as apoptotic or non-apoptotic, and may give a misleading impression of the relative importance of each. In germ cell death in Drosophila, for example, TUNEL-positive cells do not overlap with cleaved Caspase-3 staining, suggesting non-apoptotic events. ${ }^{25}$ Conversely, lack of TUNEL staining or caspase reactivity does not mean cell death is not occurring. For example, dying spinal motoneurons with LCD features are TUNEL negative. ${ }^{95,96} \mathrm{We}$ therefore believe that assigning a death type requires multiple corroborating assays, among which ultrastructural characterization of the dying cells is likely to provide the most information, and can be easily used, for example, to distinguish LCD and apoptosis. ${ }^{95}$

Non-apoptotic cell death is an exciting and largely unexplored facet of development. Because some of these cell deaths may affect animal fertility and nervous system development, the genes involved could be highly conserved and of major clinical relevance. Model systems such as C. elegans and Drosophila provide unique gene-discovery arenas that can propel our molecular understanding of nonapoptotic processes in vertebrates in much the same way these animals were used to reveal the underpinnings of apoptosis. $^{120}$

\section{Conflict of Interest}

The authors declare no conflict of interest.

Acknowledgements. Although we attempted to be as broad and complete in our citations, it is inevitable that we would have failed to cite specific literature because of our oversight or due to space constraints. For this we sincerely apologize. We thank Yun Lu for Figure 1a, Wolfgang Keil for help in designing the figures, and Caleb Hyatt for critical reading of the manuscript. LMK was supported in part by a NRSA Training Grant GM066699 and SS by NIH grants NS081490 and HD078703.

1. Lockshin RA, Williams CM. Programmed cell death-II. Endocrine potentiation of the breakdown of the intersegmental muscles of silkmoths. J Insect Physiol 1964; 10: 643-649.

2. Kerr JFR, Wyllie AH, Currie AR. Apoptosis: a basic biological phenomenon with wideranging implications in tissue kinetics. Br J Cancer 1972; 26: 239-257.

3. Ellis HM, Horvitz HR. Genetic control of programmed cell death in the nematode C. elegans. Cell 1986; 44: 817-829.

4. Xue D, Shaham S, Horvitz HR. The Caenorhabditis elegans cell-death protein CED-3 is a cysteine protease with substrate specificities similar to those of the human CPP32 protease. Genes Dev 1996; 10: 1073-1083.

5. Song Z, McCall K, Steller H. DCP-1, a Drosophila cell death protease essential for development. Science 1997; 275: 536-540.

6. Chinnaiyan AM, Chaudhary D, O'Rourke K, Koonin EV, Dixit VM. Role of CED-4 in the activation of CED-3. Nature 1997; 388: 728-729. 
7. Li P, Nijhawan D, Budihardjo I, Srinivasula SM, Ahmad M, Alnemri ES et al. Cytochrome c and dATP-dependent formation of Apaf-1/caspase-9 complex initiates an apoptotic protease cascade. Cell 1997; 91: 479-489.

8. Fuchs $\mathrm{Y}$, Steller $\mathrm{H}$. Live to die another way: modes of programmed cell death and the signals emanating from dying cells. Nat Rev Mol Cell Biol 2015; 16: 329-344.

9. Hakem R, Hakem A, Duncan GS, Henderson JT, Woo M, Soengas MS et al. Differential requirement for caspase-9 in apoptotic pathways in vivo. Cell 1998; 94: 339-352.

10. Kuida K, Zheng TS, Na S, Kuan C-Y, Yang D, Karasuyama $\mathrm{H}$ et al. Decreased apoptosis in the brain and premature lethality in CPP32-deficient mice. Nature 1996; 384: 368-372.

11. Kuida K, Haydar TF, Kuan C-Y, Gu Y, Taya C, Karasuyama H et al. Reduced apoptosis and cytochrome c-mediated caspase activation in mice lacking caspase-9. Cell 1998; 94: 325-337.

12. Cecconi F, Alvarez-Bolado G, Meyer BI, Roth KA, Gruss P. Apaf1 (CED-4 homolog) regulates programmed cell death in mammalian development. Cell 1998; 94: 727-737.

13. Yoshida H, Kong Y-Y, Yoshida R, Elia AJ, Hakem A, Hakem R et al. Apaf1 is required for mitochondrial pathways of apoptosis and brain development. Cell 1998; 94: 739-750.

14. Lindsten T, Ross AJ, King A, Zong WX, Rathmell JC, Shiels HA et al. The combined functions of proapoptotic Bcl-2 family members bak and bax are essential for normal development of multiple tissues. Mol Cell 2000; 6: 1389-1399.

15. Leonard JR, Klocke BJ, D'Sa C, Flavell RA, Roth KA. Strain-dependent neurodevelopmental abnormalities in caspase-3-deficient mice. J Neuropathol Exp Neurol 2002; 61: 673-677.

16. Honarpour N, Gilbert SL, Lahn BT, Wang X, Herz J. Apaf-1 deficiency and neural tube closure defects are found in fog mice. Proc Natl Acad Sci USA 2001; 98: 9683-9687.

17. Okamoto $\mathrm{H}$, Shiraishi $\mathrm{H}$, Yoshida $\mathrm{H}$. Histological analyses of normally grown, fertile Apaf1deficient mice. Cell Death Differ 2006; 13: 668-671.

18. Woo M, Hakem R, Soengas MS, Duncan GS, Shahinian A, Kägi D et al. Essential contribution of caspase 3/CPP32 to apoptosis and its associated nuclear changes. Genes Dev 1998; 12: 806-819.

19. Lindsten T, Thompson CB. Cell death in the absence of Bax and Bak. Cell Death Differ 2006; 13: 1272-1276.

20. Pajni-Underwood S, Wilson CP, Elder C, Mishina Y, Lewandoski M. BMP signals control limb bud interdigital programmed cell death by regulating FGF signaling. Development 2007; 134: 2359-2368.

21. Oppenheim RW. Cell death during development of the nervous system. Annu Rev Neurosci 1991; 14: 453-501.

22. Nonomura K, Yamaguchi Y, Hamachi M, Koike M, Uchiyama Y, Nakazato K et al. Local apoptosis modulates early mammalian brain development through the elimination of morphogen-producing cells. Dev Cell 2013; 27: 621-634.

23. Miura M, Chen X-D, Allen MR, Bi Y, Gronthos S, Seo B-M et al. A crucial role of caspase-3 in osteogenic differentiation of bone marrow stromal stem cells. J Clin Invest 2004; 114: 1704-1713.

24. Clarke PG. Developmental cell death: morphological diversity and multiple mechanisms. Anat Embryol 1990; 181: 195-213.

25. Yacobi-Sharon K, Namdar Y, Arama E. Alternative germ cell death pathway in Drosophila involves HtrA2/Omi, lysosomes, and a Caspase-9 counterpart. Dev Cell 2013; 25: 29-42.

26. Vercammen D, Beyaert R, Denecker G, Goossens V, Van Loo G, Declercq W et al. Inhibition of caspases increases the sensitivity of L929 cells to necrosis mediated by tumor necrosis factor. J Exp Med 1998; 187: 1477-1485.

27. Strauss KM, Martins LM, Plun-Favreau H, Marx FP, Kautzmann S, Berg D et al. Loss of function mutations in the gene encoding Omi/HtrA2 in Parkinson's disease. Hum Mol Genet 2005; 14: 2099-2111.

28. Suzuki Y, Imai Y, Nakayama H, Takahashi K, Takio K, Takahashi R. A serine protease, $\mathrm{HtrA2}$, is released from the mitochondria and interacts with XIAP, inducing cell death. Mol Cell 2001; 8: 613-621.

29. Allan DJ, Harmon BV, Roberts SA. Spermatogonial apoptosis has three morphologically recognizable phases and shows no circadian rhythm during normal spermatogenesis in the rat. Cell Prolif 1992; 25: 241-250.

30. Lee B, Park I, Jin S, Choi H, Kwon JT, Kim J et al. Impaired spermatogenesis and fertility in mice carrying a mutation in the Spink2 gene expressed predominantly in testes. J Biol Chem 2011; 286: 29108-29117.

31. Knudson MC, Tung KSK, Tourtellotte WG, Brown GAJ, Korsmey SJ. Bax-deficient mice with lymphoid hyperplasia and male germ cell death. Science 1995; 270: 96-99.

32. Rodriguez I, Ody C, Araki K, Garcia I, Vassalli P. An early and massive wave of germinal cell apoptosis is required for the development of functional spermatogenesis. EMBO J 1997; 16: 2262-2270.

33. Jenkins VK, Timmons AK, McCall K. Diversity of cell death pathways: insight from the fly ovary. Trends Cell Biol 2013; 23: 567-574.

34. Cavaliere V, Taddei C, Gargiulo G. Apoptosis of nurse cells at the late stages of oogenesis of Drosophila melanogaster. Dev Genes Evol 1998; 208: 106-112.

35. Bass BP, Tanner EA, Mateos San Martín D, Blute T, Kinser RD, Dolph PJ et al. Cell-autonomous requirement for DNasell in nonapoptotic cell death. Cell Death Differ 2009; 16: 1362-1371.

36. Nezis IP, Shravage BV, Sagona AP, Lamark T, Bjørkøy G, Johansen T et al. Autophagic degradation of dBruce controls DNA fragmentation in nurse cells during late Drosophila melanogasteroogenesis. J Cell Biol 2010; 190: 523-531.
37. Peterson JS, Barkett M, McCall K. Stage-specific regulation of caspase activity in drosophila oogenesis. Dev Biol 2003; 260: 113-123.

38. Mazzalupo S, Cooley L. Illuminating the role of caspases during Drosophila oogenesis. Cell Death Differ 2006; 13: 1950-1959.

39. Bass BP, Cullen K, McCall K. Axon guidance gene lola is required for programmed cell death in the Drosophila ovary. Dev Biol 2007; 304: 771-785.

40. Foley K, Cooley L. Apoptosis in late stage Drosophila nurse cells does not require genes within the H99 deficiency. Development 1998; 125: 1075-1082.

41. Peterson JS, Bass BP, Jue D, Rodriguez A, Abrams JM, McCall K. Noncanonical cell death pathways act during Drosophila oogenesis. Genesis 2007; 45: 396-404.

42. Baum JS, Arama E, Steller H, McCall K. The Drosophila caspases Strica and Dronc function redundantly in programmed cell death during oogenesis. Cell Death Differ 2007 14: $1508-1517$.

43. Xu D, Li Y, Arcaro M, Lackey M, Bergmann A. The CARD-carrying caspase Dronc is essential for most, but not all, developmental cell death in Drosophila. Development 2005 132: 2125-2134.

44. Laundrie B, Peterson JS, Baum JS, Chang JC, Fileppo D, Thompson SR et al. Germline cell death is inhibited by P-element insertions disrupting the $d c p-1 /$ pita nested gene pair in Drosophila. Genetics 2003; 165: 1881-1888.

45. Nezis IP, Stravopodis DJ, Margaritis LH, Papassideri IS. Chromatin condensation of ovarian nurse and follicle cells is regulated independently from DNA fragmentation during Drosophila late oogenesis. Differentiation 2006; 74: 293-304.

46. Mukae N, Yokoyama H, Yokokura T, Sakoyama Y, Nagata S. Activation of the innate immunity in Drosophila by endogenous chromosomal DNA that escaped apoptotic degradation. Genes Dev 2002; 16: 2662-2671.

47. Peterson JS, McCall K. Combined inhibition of autophagy and caspases fails to preven developmental nurse cell death in the Drosophila melanogaster ovary. PLOS ONE 2013; 8 : e76046-e76048.

48. Timmons AK, Mondragon AA, Schenkel CE, Yalonetskaya A, Taylor JD, Moynihan KE et al. Phagocytosis genes nonautonomously promote developmental cell death in the Drosophila ovary. Proc Natl Acad Sci USA 2016; 113: E1246-E1255.

49. Jiang C, Baehrecke EH, Thummel CS. Steroid regulated programmed cell death during Drosophila metamorphosis. Development 1997; 124: 4673-4683.

50. Berry DL, Baehrecke EH. Growth arrest and autophagy are required for salivary gland cell degradation in Drosophila. Cell 2007; 131: 1137-1148.

51. Lee C-Y, Baehrecke EH. Steroid regulation of autophagic programmed cell death during development. Development 2001; 128: 1443-1455.

52. Martin DN, Baehrecke EH. Caspases function in autophagic programmed cell death in Drosophila. Development 2004; 131: 275-284.

53. Gorski SM, Chittaranjan S, Pleasance ED, Freeman JD, Anderson CL, Varhol RJ et al. A SAGE approach to discovery of genes involved in autophagic cell death. Curr Biol 2003; 13: 358-363.

54. Lee C-Y, Clough EA, Yellon P, Teslovich TM, Stephan DA, Baehrecke EH. Genome-wide analyses of steroid- and radiation-triggered programmed cell death in Drosophila. Curr Biol 2003; 13: 350-357.

55. Muro I, Berry DL, Huh JR, Chen $\mathrm{CH}$, Huang H, Yoo SJ et al. The Drosophila caspase Ice is important for many apoptotic cell deaths and for spermatid individualization, a nonapoptotic process. Development 2006; 133: 3305-3315.

56. McPhee CK, Logan MA, Freeman MR, Baehrecke EH. Activation of autophagy during cell death requires the engulfment receptor Draper. Nature 2010; 465: 1093-1096.

57. Wu YC, Stanfield GM, Horvitz HR. NUC-1, a Caenorhabditis elegans DNase II homolog, functions in an intermediate step of DNA degradation during apoptosis. Genes Dev 2000; 14: $536-548$

58. Abraham MC, Lu Y, Shaham S. A morphologically conserved nonapoptotic program promotes linker cell death in Caenorhabditis elegans. Dev Cell 2007; 12: 73-86.

59. Denning DP, Hatch V, Horvitz HR. Both the caspase csp-1 and a caspase-independent pathway promote programmed cell death in parallel to the canonical pathway for apoptosis in Caenorhabditis elegans. PLoS Genet 2013; 9: e1003341-15.

60. Kimble J. Alterations in cell lineage following laser ablation of cells in the somatic gonad of Caenorhabditis elegans. Dev Biol 1981; 87: 286-300.

61. Kinet MJ, Malin JA, Abraham MC, Blum ES, Silverman MR, Lu Y et al. HSF-1 activates the ubiquitin proteasome system to promote non-apoptotic developmental cell death in C. elegans. Elife 2016; 5: 73.

62. Malin JA, Kinet MJ, Abraham MC, Blum ES, Shaham S. Transcriptional control of non-apoptotic developmental cell death in C. elegans. Cell Death Differ 2016; 23: 1-10.

63. Blum ES, Abraham MC, Yoshimura S, Lu Y, Shaham S. Control of nonapoptotic developmental cell death in Caenorhabditis elegans by a polyglutamine-repeat protein. Science 2012; 335: 970-973.

64. Horvitz HR, Sternberg PW, Greenwald IS, Fixsen W, Ellis HM. Mutations that affect neura cell lineages and cell fates during the development of the nematode Caenorhabditis elegans. Cold Spring Harb Symp Quant Biol 1983; 48: 453-463.

65. Lunn ER, Perry VH, Brown MC, Rosen H, Gordon S. Absence of Wallerian degeneration does not hinder regeneration in peripheral nerve. Eur J Neurosci 1989; 1: 27-33.

66. Mack TG, Reiner M, Beirowski B, Mi W, Emanuelli M, Wagner D et al. Wallerian degeneration of injured axons and synapses is delayed by a Ube4b/Nmnat chimeric gene. Nat Neurosci 2001; 4: 1199-1206. 
67. Osterloh JM, Yang J, Rooney TM, Fox AN, Adalbert R, Powell EH et al. dSarm/Sarm1 is required for activation of an injury-induced axon death pathway. Science 2012; 337 481-484.

68. Gerdts J, Summers DW, Sasaki Y, DiAntonio A, Milbrandt J. Sarm1-mediated axon degeneration requires both SAM and TIR interactions. J Neurosci 2013; 33: 13569-13580.

69. Blum ES, Schwendeman AR, Shaham S. PolyQ disease: misfiring of a developmental cell death program? Trends Cell Biol 2013; 23: 168-174.

70. Davies SW, Turmaine M, Cozens BA, DiFiglia M, Sharp AH, Ross CA et al. Formation of neuronal intranuclear inclusions underlies the neurological dysfunction in mice transgenic for the HD mutation. Cell 1997; 90: 537-548.

71. Turmaine M, Raza A, Mahal A, Mangiarini L, Bates GP, Davies SW. Nonapoptotic neurodegeneration in a transgenic mouse model of Huntington's disease. Proc Natl Acad Sci USA 2000; 97: 8093-8097.

72. Bots GT, Bruyn GW. Neuropathological changes of the nucleus accumbens in Huntington's chorea. Acta Neuropathol 1981; 55: 21-22.

73. Skinner PJ, Koshy BT, Cummings CJ, Klement IA, Helin K, Servadio A et al. Ataxin-1 with an expanded glutamine tract alters nuclear matrix-associated structures. Nature 1997; 389 971-974.

74. Evert BO, Wüllner U, Schulz JB, Weller M, Groscurth $P$, Trottier $Y$ et al. High level expression of expanded full-length ataxin-3 in vitro causes cell death and formation of intranuclear inclusions in neuronal cells. Hum Mol Genet 1999; 8: 1169-1176.

75. Takahashi H, Egawa S, Piao Y-S, Hayashi S, Yamada M, Shimohata T et al. Neurona nuclear alterations in dentatorubral-pallidoluysian atrophy: ultrastructural and morphometric studies of the cerebellar granule cells. Brain Res 2001; 919: 12-19.

76. Zander C, Takahashi J, Hachimi El KH, Fujigasaki H, Albanese V, Lebre AS et al. Similarities between spinocerebellar ataxia type 7 (SCA7) cell models and human brain: proteins recruited in inclusions and activation of caspase-3. Hum Mol Genet 2001; 10 2569-2579.

77. Maat-Schieman ML, Dorsman JC, Smoor MA, Siesling S, Van Duinen SG, Verschuuren JJ et al. Distribution of inclusions in neuronal nuclei and dystrophic neurites in Huntington disease brain. J Neuropathol Exp Neurol 1999; 58: 129-137.

78. Schwartz LM, Smith SW, Jones MEE, Osborne BA. Do all programmed cell deaths occur via apoptosis? Proc Natl Acad Sci USA 1993; 90: 980-984.

79. Schwartz LM, Myer A, Kosz L, Engelstein M, Maier C. Activation of polyubiquitin gene expression during developmentally programmed cell death. Neuron 1990; 5: 411-419.

80. Haas AL, Baboshina O, Williams B, Schwartz LM. Coordinated induction of the ubiquitin conjugation pathway accompanies the developmentally programmed death of insect skeletal muscle. J Biol Chem 1995; 270: 9407-9412.

81. Kelliher MA, Grimm S, Ishida Y, Kuo F, Stanger BZ, Leder P. The death domain kinase RIP mediates the TNF-induced NF-kappaB signal. Immunity 1998; 8: 297-303.

82. Li P, Allen H, Banerjee S, Franklin S, Herzog L, Johnston C et al. Mice deficient in IL-1 $\beta$ converting enzyme are defective in production of mature $\mathrm{IL}-1 \beta$ and resistant to endotoxic shock. Cell 1995; 80: 401-411.

83. Schweichel JU, Merker HJ. The morphology of various types of cell death in prenatal tissues. Teratology 1973; 7: 253-266.

84. Candi E, Schmidt R, Melino G. The cornified envelope: a model of cell death in the skin. Nat Rev Mol Cell Biol 2005; 6: 328-340.

85. Kreuzaler PA, Staniszewska AD, Li W, Omidvar N, Kedjouar B, Turkson J et al. Stat3 controls lysosomal-mediated cell death in vivo. Nat Cell Biol 2011; 13: 303-309.

86. Oppenheim RW, Flavell RA, Vinsant S, Prevette D, Kuan C-Y, Rakic P. Programmed cell death of developing mammalian neurons after genetic deletion of caspases. J Neurosci 2001; 21: 4752-4760.

87. Enari M, Sakahira H, Yokoyama H, Okawa K, Iwamatsu A, Nagata S. A caspase-activated DNase that degrades DNA during apoptosis, and its inhibitor ICAD. Nature 1998; 391 43-50.

88. Sun W, Gould TW, Vinsant S, Prevette D, Oppenheim RW. Neuromuscular development after the prevention of naturally occurring neuronal death by Bax deletion. J Neurosci 2003 23: $7298-7310$.

89. Oppenheim RW, Blomgren K, Ethell DW, Koike M, Komatsu M, Prevette D et al. Developing postmitotic mammalian neurons in vivo lacking Apaf-1 undergo programmed cell death by a caspase-independent, nonapoptotic pathway involving autophagy. J Neurosci 2008; 28 : $1490-1497$.

90. Hamburger V, Levi-Montalcini R. Proliferation, differentiation and degeneration in the spinal ganglia of the chick embryo under normal and experimental conditions. J Exp Zool 1949; 111: 457-501.

91. O'Connor TM, Wyttenbach CR. Cell death in the embryonic chick spinal cord. J Cell Bio 1974; 60: 448-459.

92. Chu-Wang IW, Oppenheim RW. Cell death of motoneurons in the chick embryo spinal cord. J Comp Neurol 1978; 177: 33-58.
93. Borsello T, Mottier V, Castagné V, Clarke PGH. Ultrastructure of retinal ganglion cell death after axotomy in chick embryos. J Comp Neurol 2002; 453: 361-371.

94. Pilar G, Landmesser L. Ultrastructural differences during embryonic cell death in normal and peripherally deprived ciliary ganglia. J Cell Biol 1976; 68: 339-356.

95. Brunet N, Tarabal O, Portero-Otín M, Oppenheim RW, Esquerda JE, Calderó J. Survival and death of mature avian motoneurons in organotypic slice culture: trophic requirements for survival and different types of degeneration. J Comp Neurol 2007; 501: 669-690.

96. Yaginuma H, Shiraiwa N, Shimada T, Nishiyama K, Hong J, Wang S et al. Caspase activity is involved in, but is dispensable for, early motoneuron death in the chick embryo cervical spinal cord. Mol Cell Neurosci 2001; 18: 168-182.

97. Pampfer S, Donnay I. Apoptosis at the time of embryo implantation in mouse and rat. Cell Death Differ 1999; 6: 533-545.

98. El-Shershaby AM, Hinchliffe JR. Cell redundancy in the zona-intact preimplantation mouse blastocyst: a light and electron microscope study of dead cells and their fate. J Embryol Exp Morphol 1974; 31: 643-654.

99. Zhang $Q$, Paria BC. Importance of uterine cell death, renewal, and their hormonal regulation in hamsters that show progesterone-dependent implantation. Endocrinology 2011; 147: 2215-2227.

100. Leidenfrost S, Boelhauve M, Reichenbach M, Güngör T, Reichenbach H-D, Sinowatz F et al. Cell arrest and cell death in mammalian preimplantation development: lessons from the bovine model. PLOS ONE 2011; 6: e22121-13.

101. Parr EL, Tung HN, Parr MB. Apoptosis as the mode of uterine epithelial cell death during embryo implantation in mice and rats. Biol Reprod 1987; 36: 211-225.

102. El-Shershaby AM, Hinchliffe JR. Epithelial autolysis during implantation of the mouse blastocyst: an ultrastructural study. J Embryol Exp Morphol 1975; 33: 1067-1080.

103. Li Y, Sun X, Dey SK. Entosis allows timely elimination of the luminal epithelial barrier for embryo implantation. Cell Rep 2015; 11: 358-365.

104. Overholtzer M, Mailleux AA, Mouneimne G, Normand G, Schnitt SJ, King RW et al. A nonapoptotic cell death process, entosis, that occurs by cell-in-cell invasion. Cell 2007; 131: 966-979.

105. Mullen RD, Behringer RR. Molecular genetics of Müllerian duct formation, regression and differentiation. Sex Dev 2014; 8: 281-296.

106. Cate RL, Mattaliano RJ, Hession C, Tizard R, Farber NM, Cheung A et al. Isolation of the bovine and human genes for Müllerian inhibiting substance and expression of the human gene in animal cells. Cell 1986; 45: 685-698.

107. Kobayashi A, Stewart CA, Wang Y, Fujioka K, Thomas NC, Jamin SP et al. b-Catenin is essential for mullerian duct regression during male sexual differentiation. Development 2011; 138: 1967-1975.

108. Dyche WJ. A comparative study of the differentiation and involution of the Müllerian duct and Wolffian duct in the male and female fetal mouse. J Morphol 1979; 162: 175-210.

109. Price JM, Donahoe PK, Ito Y, Hendren WH III. Programmed cell death in the Müllerian duct induced by Müllerian inhibiting substance. Am J Anat 1977; 149: 353-376.

110. Djehiche B, Segalen J, Chambon Y. Ultrastructure of Müllerian and Wolffian ducts of fetal rabbit in vivo and in organ culture. Tissue Cell 1994; 26: 323-332.

111. Price JM, Donahoe PK, Ito Y. Involution of the female Müllerian duct of the fetal rat in the organ-culture assay for the detection of Müllerian inhibiting substance. Am J Anat 1979; 156: $265-284$

112. Allard S, Adin P, Gouedard L, di Clemente N, Josso N, Orgebin-Crist M-C et al. Molecular mechanisms of hormone-mediated Müllerian duct regression: involvement of b-catenin. Development 2000; 127: 3349-3360.

113. Parr BA, McMahon AP. Sexually dimorphic development of the mammalian reproductive tract requires Wnt-7a. Nature 1998; 395: 707-710.

114. Behringer RR, Finegold MJ, Cate RL. Müllerian-inhibiting substance function during mammalian sexual development. Cell 1994; 79: 415-425.

115. Mishina Y, Rey R, Finegold MJ, Matzuk MM, Josso N, Cate RL et al. Genetic analysis of the Müllerian-inhibiting substance signal transduction pathway in mammalian sexual differentiation. Genes Dev 1996; 10: 2577-2587.

116. Orvis GD, Jamin SP, Kwan KM, Mishina Y, Kaartinen VM, Huang S et al. Functional redundancy of TGF-beta family type I receptors and receptor-Smads in mediating antiMullerian hormone-induced Mullerian duct regression in the mouse. Biol Reprod 2008; 78 : 994-1001.

117. Roberts LM, Visser JA, Ingraham HA. Involvement of a matrix metalloproteinase in MISinduced cell death during urogenital development. Development 2002; 129: 1487-1496.

118. Itoh T, Ikeda T, Gomi H, Nakao S, Suzuki T, Itohara S. Unaltered secretion of beta-amyloid precursor protein in gelatinase A (matrix metalloproteinase 2)-deficient mice. J Biol Chem 1997; 272: 22389-22392.

119. Blelloch R, Kimble J. Control of organ shape by a secreted metalloprotease in the nematode Caenorhabditis elegans. Nature 1999: 399: 586-590.

120. Horvitz HR. Nobel lecture: worms, life and death. Biosci Rep 2003; 23: 239-303. 